\title{
2016 Child Poverty Rate Sees Largest Decline Since Before Great Recession
}

\section{Poverty Persists as Challenge for the United States}

Marybeth J. Mattingly, Andrew Schaefer, and Jessica A. Carson



hild poverty declined by 1.2 percentage points between 2015 and 2016, according to analyses of the official poverty measure (OPM) in the latest American Community Survey. By 2016, child poverty across the nation was still 1.5 percentage points higher than before the Great Recession. Child poverty remained higher in cities and rural places than in the suburbs. Across the nation there is substantial variability both in the level of poverty and in improvement since the start of the Great Recession-25 states have child poverty rates higher than those in 2007 (see what's happening in your state*). Of course, the official poverty measure is only one indicator of economic challenge, and many families living above the poverty line still struggle to make ends meet.

\section{PERCENT OF CHILDREN IN POVERTY BY PLACE TYPE, 2007-2016}



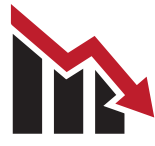

The Great Recession officially lasted from December 2007 to June 2009, but it continues to influence U.S. economic trends.

See related publications at carsey.unh.edu

- Gains in Reducing Child Poverty, but Racial-Ethnic Disparities Persist (April 2017)

$>$ Overall Declines in Child Poverty Mask Relatively Stable Rates Across States (September 2016)

- Child Poverty Higher and More Persistent in Rural America (February 2016)

This research was funded by the Annie E. Casey Foundation and anonymous donors.

Note: * Available at http://unh.me/DmFJ30f9Q1K

Analysis: M.J. Mattingly, A. Schaefer, and J.A. Carson, Carsey School, University of New Hampshire

Source: 2007-2016 American Community Survey, U.S. Census Bureau

Huddleston Hall • 73 Main Street • Durham, NH 03824 carsey.unh.edu $\bullet 603.862 .2821$
TTY USERS: DIAL 7-1-1 OR

1-800-735-2964 (Relay N.H.) 